\title{
HUBUNGAN IKLIM KERJA ORGANISASI DENGAN MOTIVASI KERJA PEGAWAI DI SANGGAR KEGIATAN BELAJAR (SKB) KOTA BINJAI
}

\author{
Rini Pratiwi Br Ginting ${ }^{(1)}$, Anifah ${ }^{(2)}$, Vidya Dwi Amalia Zati ${ }^{(1)}$, \\ Sani Susanti ${ }^{(2)}$ \\ ${ }^{(1)}$ Mahasiswa Jurusan Pendidikan Masyarakat, Universitas Negeri Medan \\ ${ }^{(2)}$ Dosen Jurusan Pendidikan Masyarakat, Universitas Negeri Medan \\ ${ }^{(3)}$ Dosen Jurusan Pendidikan Masyarakat, Universitas Negeri Medan \\ ${ }^{(4)}$ Dosen Jurusan Pendidikan Masyarakat, Universitas Negeri Medan \\ Jl. Williem Iskandar Pasar V Medan Estate, Medan, Sumatera Utara,20371
}

Email: anifah.pilcan@gmail.com

\begin{abstract}
Abstrak: Masalah dalam penelitian ini salah satu diantaranya adalah rendahnya tingkat kinerja sumber daya manusia. Rendahnya tingkat kinerja pegawai salah satunya dapat dipengaruhi oleh iklim kerja dan motivasi kerja. Dengan semakin kondusifnya iklim kerja, maka akan mempengaruhi kinerja pegawai dan meningkatkan motivasi kerja pegawai tersebut.. Penelitian ini bertujuan untuk mengetahui hubungan antara iklim kerja pegawai dengan motivasi kerja di SKB Kota Binjai. Penelitian ini dilakukan pada SKB Kota Binjai. Metode yang digunakan dalam penelitian ini adalah deskriptif kuantitatif. Sampel dalam penelitia ini adalah 30 orang pegawai yang bekerja pada SKB Kota Binjai. Teknik pengumpulan data yang digunakan adalah angket. Dan teknik analisis data yang digunakan adalah regresi linier sederhana dan uji t. Berdasarkan pengelolaan data dengan regresi linier sederhana diperoleh persamaan regresi linier adalah $\hat{Y}=0,379+0,981 x$. Hasil uji hipotesis dengan uji $t$ diperoleh nilai $t_{\text {hitung }}(11,506)>t_{\text {tabel }}(1,701)$. Artinya terdapat hubungan iklim kerja pegawai dengan motivasi kerja di SKB Kota Binjai. Terbentuknya iklim kerja yang kondusif pada tempat kerja dapat menjadi actor penunjang bagi peningkatan kinerja sebab kenyamanan dalam bekerja membuat pegawai berpikir dengan tenang dan terkonsentrasi hanya pada tugas yang sedang dilaksanakan. Maka dapat disimpulkan apabila iklim kerja pegawai baik maka akan berdampak baik pula terhadap motivasi kerja di SKB Kota Binjai.
\end{abstract}

Kata kunci : Iklim Kerja Organisasi dan Motivasi Kerja Pegawai di SKB Kota Binjai

\section{PENDAHULUAN}

Pendidikan adalah usaha sadar dan terencana untuk mewujudkan suasana proses belajar dan proses pembelajaran agar peserta didik secara aktif mengembangkan potensi dirinya untuk memiliki kekuatan spiritual keagamaan, pengendalian diri, kepribadian, kecerdasan, akhlak mulia, serta keterampilan yang diperlukan dirinya, masyarakat, bangsa, dan Negara (Undang-Undang Sistem Pendidikan Nasional Nomor 20 Tahun 2003). Dalam Undang-Undang Sistem Pendidikan Nasional No. 20 Tahun 2003 ditegaskan bahwa pelayanan pendidikan bagi masyarakat Indonesia diselenggarakan dalam tiga jalur pendidikan, yaitu jalur pendidikan formal, informal, dan non formal yang dapat saling melengkapi dan memperkaya. Hal ini juga sejalan dengan pendapat Sudjana (2000:74) bahwa "Pendidikan Luar Sekolah (PLS) mempunyai peran sebagai 
pelengkap, penambah dan pengganti pendidikan sekolah". Dalam UndangUndang juga dijelaskan bahwa Pendidikan Non Formal diselenggarakan bagi warga masyarakat yang membutuhkan pendidikan yang berfungsi sebagai pengganti, penambah, dan pelengkap pendidikan formal dalam rangka mendukung pendidikan sepanjang hayat. Selain dari pada itu pula ditegaskan bahwa pendidikan non formal berfungsi untuk mengembangkan potensi peserta didik atau warga belajar dengan lebih menekankan pada penguasaan pengetahuan dan keterampilan fungsional serta pengembangan sikap dan kepribadian profesional. Kegiatan Belajar erat kaitannya dengan sumber daya manusia yang menjadi pelaku program untuk dapat berbuat secara serius dalam melaksanakan pekerjaannya yang dalam hal ini salah satunya adalah pegawai SKB. Yang dimaksud sebagai pegawai Sanggar Kegiatan Belajar (SKB) adalah pendidik dan tenaga kependidikan yang berada di SKB tersebut.

Di Indonesia tersebar di seluruh Kabupaten/Kota pada 26 provinsi Sumatera Utara kurang lebih sebanyak 260 Sanggar Kegiatan Belajar (SKB). Namun dari tahun ketahun mengalami penurunan dalam pelaksanaan program PNF. Faktor penyebab menurunnya kualitas SKB di Indonesia adalah jumlah ideal pegawai khususnya pamong belajar yang tersedia dan bekerja di SKB 2.699 orang, dengan asumsi setiap SKB di Indonesia harus memiliki 35 orang maksimal pamong belajar (Dit.Bin.PPTK PAUDNI 2013). Namun saat ini jumlah tersebut belum mencukupi. Faktor lain yang memhubungani penurunan kualitas Sanggar Kegiatan Belajar (SKB) adalah fasilitas kerja yang kurang memadai sehingga pegawai kurang memotivasi untuk melaksanakan pekerjaannya secara optimal. Hal ini dapat mengakibatkan banyaknya SKB di Indonesia yang tidak aktif. Khususnya di Sumatera Utara terdapat 20 Sanggar Kegiatan Belajar (SKB) (BP-PAUDNI Regional I tahun 2013) yang berada di Kabupaten/Kota. Namun saat ini hanya sedikit SKB yang dapat bertahan untuk melaksanakan berbagai macam program untuk meningkatkan potensi masyarakat, salah satunya yaitu Sanggar Kegiatan Belajar (SKB) di Kota Binjai. Selebihnya SKB mengalami penurunan dalam pelaksanaan program PNF. Hal ini terjadi karena rendahnya kualitas Sanggar Kegiatan Belajar dan didukung oleh rendahnya kinerja pegawai Sanggar Kegiatan Belajar.

Produktivitas kerja karyawan dihubungani oleh motivasi kerja (motivation) dan kepemimpinan. Motivasi kerja merupakan indikator yang mampu membuat seorang karyawan lebih puas dalam menjalankan aktivitasnya. Motivasi kerja adalah proses sebagai langkah awal seseorang melakukan tindakan akibat kekurangan secara fisik dan psikis, yaitu suatu 
dorongan yang ditunjukkan untuk memenuhi tujuan tertentu. Setiap kegiatan yang dilakukan oleh seseorang didorong oleh suatu kekuasaan dalam diri orang tersebut, kekuatan pendorong inilah yang disebut motivasi kerja. "Motivasi menyangkut soal perilaku manusia dan merupakan elemen vital didalam manajemen. Motivasi dapat diartikan sebagai mengusahakan supaya seseorang dapat menyelesaikan pekerjaan dengan semangat karena ia ingin melaksanakannya" (Terry,2009:130).

Setiap orang yang bekerja di SKB memerlukan rasa aman, nyaman dan menyenangkan. Hal tersebut dapat diperoleh dalam lingkungan kerja yang sehat dan kondusif. Keberadaan iklim kerja yang sehat memungkinkan setiap orang untuk bekerja secara lebih baik sehingga kelancaran tugasnya dapat tercapai dengan hasil yang maksimal. Sanggar kegiatan belajar merupakan suatu sistem kerja yang di dalamnya memiliki kegiatan kerjasama dan tata nilai yang membentuk suatu kondisi atau sering disebut iklim kerja. Hal tersebut menunjukkan bahwa iklim kerja merupakan suasana kerja yang dirasakan oleh setiap pegawai dalam melakukan suatu aktivitas kerja. Jadi jelas iklim kerja terkait dengan kondisi dan suasana kerja yang merupakan dampak yang ditimbulkan dari keberadaan komponen Sanggar Kegiatan Belajar, baik berupa material maupun non material yang menghasilkan suatu bentuk dan warna kehidupan tersendiri.

Gibson, Ivancevich dan Donelly (dalam Carudin, http://www.academia.edu, 2011:133) menyatakan bahwa iklim organisasi adalah serangkaian keadaan lingkungan yang dirasakan secara langsung dan tidak langsung oleh karyawan. Artinya bahwa iklim organisasi sebagai beberapa keadaan atau kondisi dalam satu rangkaian yang secara langsung atau tidak langsung, sadar atau tidak sadar, dapat memhubungani karyawan". Begitupun dengan lingkungan kerja yang ada di dalam lembaga Sanggar Kegiatan Belajar Kota Binjai, yang merupakan kumpulan individu-indvidu atau sekelompok orang yang dalam sebuah organisasai dengan latar belakang yang berbeda dan proses suatu sistem kerja yang ada di dalam organisasi tersebut memiliki kegiatan kerjasama dan tata nilai yang membentuk proses atau aktivitas.

Berdasarkan pengalaman yang dilakukan penulis selama observasi di Sanggar Kegiatan Belajar (SKB) kota Binjai, pada kenyataannnya SKB ini sebagai SKB yang banyak diminati oleh masyarakat setempat pernah mengalami penurunan kualitas, hal ini dapat dibuktikan dari berkurangnya program yang dilaksanakan di SKB tersebut. Di SKB ternyata kurang terjalinnya kerja sama yang efektif terkait tugas-tugas pegawai perminggu bahkan perbulannya. Kepala Sanggar Kegiatan Belajar (SKB) lebih sering 
memantau secara tidak langsung sehingga ada pegawai yang kelihatan santai dan hanya bekerja jika ada perintah dari kepada Sanggar Kegiatan Belajar (SKB) saja. Lingkungan kerja tersebut jika terus berlanjut akan menimbulkan komunikasi yang kurang lancar antara kepala SKB dengan pegawai.

Selain komunikasi yang kurang lancar Sanggar Kegiatan Belajar juga memiliki fasilitas kerja yang kurang memadai, dapat dilihat dari penataan ruang kerja pamong belajar dan ruangan tata usaha. Ukuran ruang kerja pamong belajar adalah $7 \mathrm{~m} \times 6 \mathrm{~m}$, yang memiliki fasilitas kamar mandi, gudang, meja sebanyak 12 buah, kursi 15 buah dan juga lemari sebanyak 4 buah. Sedangkan penataan ruang kerja tata usaha memiliki meja sebanyak 6 buah, kursi 5, dan 1 buah unit komputer beserta printer. Penataan yang kurang baik untuk faslitas yang kurang memadai tersebut kemungkinan menimbulkan rasa tidak nyaman pegawai SKB. Rasa tidak nyaman yang dirasakan pegawai dapat menimbulkan kejenuhan dan sedikit waktu pegawai di dalam ruangan kerja. Sebagian pegawai yang dilihat oleh peneliti waktu melakukan observasi dilapangan masih memilih dudukduduk pada saat jam kerja. Sehingga interaksi antara sesama pegawai kurang lancar. Selain itu juga ada pegawai yang menunjukkan motivasi kerja yang rendah dan bahkan yang tinggi.

\section{KAJIAN TEORI}

Seperti yang dikemukakan Henry dan Kurt (Saondi, 2010: 45) mengatakan bahwa "iklim kerja organisasi adalah seperangkat karakteristik yang membedakan antara individu satu dengan individu lainnya yang dapat memhubungani perilaku individu itu sendiri. Perilaku merupakan hasil dari hubungan antara individu dengan lingkungannya". Keberhasilan dari suatu lembaga dapat tercapai apabila sifat-sifat lingkungan kerja ini adalah menyangkut semua lingkungan sosial yang dirasakan tutor, hal ini mencerminkan bahwa iklim kerja berhubungan dengan motivasi kerja tutor.

Itu sebabnya iklim kerja sangat dibutuhkan dalam sebuah lembaga untuk memberikan lingkungan kerja yang baik sehingga motivasi kerja pegawai dapat menunjang keberhasilan Sanggar Kegiatan Belajar (SKB). Untuk mengawali proses motivasi kerja pegawai, yang paling penting adalah pada situasi dimana lingkungan kerja dalam Sanggar Kegiatan Belajar (SKB) menunjang sebagai upaya peningkatan produktifitas motivasi kerja pegawai. Hal ini penting karena lingkungan kerja akan memhubungani iklim kerja secara keseluruhan. 
Hal ini juga sesuai dengan pendapat Wulyo (Wahyudin, 2012: 100) yang menyatakan motivasi adalah seluruh proses gerakan, termaksud situasi yang mendorong timbulnya kekuatan pada diri individu, sikap yang dihubungani untuk pencapaian suatu tujuan. Dengan pengertian bahwa tercapai pula tujuan pribadi para pegawai. Oleh karena itu Sanggar Kegiatan Belajar (SKB) harus mampu menciptakan suatu kondisi dimana para pegawai akan merasa bahwa kehadirannya benar-benar dibutuhkan oleh pihak lembaga, sehingga ia akan termotivasi untuk selalu bekerja dengan baik dan penuh tanggungjawab, sehingga mendorong seorang pegawai belajar untuk bisa meningkatkan prestasinya karena adanya dorongan dirinya berdasarkan keadaan dan kondisi lingkungan kerjanya yang mendukung.

Iklim kerja (variabel X) adalah variabel bebas yang artinya tidak tergantung atau memhubungani oleh variabel lain. Sedangkan motivasi kerja (variabel Y) merupakan variabel terikat yang dihubungani dan ditentukan oleh variable terikat. Oleh sebab itu tinggi, rendah, sedang, atau rendah sekali motivasi kerja pegawai yang ada di Sanggar Kegiatan Belajar (SKB) tergantung iklim kerja. Artinya jika iklim kerja yang diciptakan disana dengan baik maka akan baik pula pada motivasi para pegawai di Sanggar Kegiatan Belajar (SKB) Kota Binjai tersebut.

\section{METODE PENELITIAN}

Dalam penelitian ini, penulis menggunakan jenis penelitian Kuantitatif dengan pendekatana Asosiatif. Sugiyono (2012:36) menyatakan bahwa rumusan masalah yang bersifat menanyakan hubungan antara dua variabel atau lebih, baik hubungan simetris, hubungan kasual, dan hubungan interaktif atau timbal balik. Penulis memilih jenis penelitian ini karena dianggap tepat untuk dapat menggambarkan hubungan antara iklim kerja organisasi dengan motivasi kerja pegawai di Sanggar Kegiatan Belajar (SKB) Kota Binjai.

Menurut Mudrajad (Rumengan, 2010:162) "Populasi adalah sekelompok elemen yang lengkap, yang biasa berupa orang, objek, transaksi atau kejadian dimana kita tertarik untuk mempelajarinya atau menjadi objek penelitian. Maka yang menjadi populasi dalam penelitian ini adalah 30 orang pegawai yang melaksanakan tugas Di UPTD Pusat Kegiatan Belajar Masyarakat (Sanggar Kegiatan Belajar (SKB) Kota Binjai. Jumlah sampel yang ingin diteliti adalah sebanyak 30 orang pegawai di Sanggar Kegiatan Belajar (SKB) Kota Binjai. Dalam penelitian ini teknik penulis 
memiliki teknik sampling jenuh karena seluruh jumlah populasi dijadikan sampel dalam penelitian ini.

Teknik pengumpulan data yang digunakan dalam penelitian ini adalah angket, yaitu dengan cara menyebarkan angket pada setiap pegawai. Angket yang digunakan adalah angket yang bersifat tertutup yang sudah disediakan jawabanya sesuai dengan karakteristik dirinya dan alat ukur yang digunakan yaitu Skala likert. Skala likert banyak digunakan untuk mengukur sikap, opini, dan persepsi seorang atau sekelompok terhadap suatu fenomena sosial termasuk pendidikan (Masyhud, 2014:225). Pilihan jawaban memiliki skor sebagai berikut :

a. Sangat setuju : 4

b. Setuju : 3

c. Kurang Setuju :2

d. Tidak Setuju : 1

Jumlah pertanyaan dalam angket sebanyak 40 pernyataan yang mewakili masing-masing variabel, yaitu Iklim Kerja Organisasi dan Motivasi Kerja Pegawai Sanggar Kegiatan Belajar (SKB) Kota Binjai.

Uji hipotesis digunakan untuk mengetahui apakah terdapat hubungan antara iklim kerja dengan motivasi kerja.

Ho : Tidak dapat hubungan antara iklim kerja organisasi dengan motivasi kerja di SKB Kota Binjai

Ha : Terdapat hubungan antara iklim kerja organisasi dengan motivasi kerja di SKB Kota Binjai

Untuk menentukan apakah hipotesis yang dirumuskan depat diterima atau tidak digunakan uji " $\mathrm{t}$ " dengan rumus :

$$
\mathrm{t}_{\text {hitung }}=\frac{\mathrm{r} \sqrt{(\mathrm{N}-2)}}{\sqrt{\left(1-\mathrm{r}^{2}\right)}}
$$

Keterangan :

$\mathrm{t}=$ menunjukkan nilai standar deviasi dari distribusi $\mathrm{t}$

$\mathrm{r}=$ koefisien korelasi

$\mathrm{N}=$ jumlah responden

Selanjutnya nilai $t_{\text {hitung }}$ dibandingkan dengan nilai $t_{\text {tabel }}$. Dengan kesalahan $5 \%$ dengan rerajat kebebasan $(\mathrm{dk})=\mathrm{n}-2$, maka :

Ho : diterima jika, $t$ hitung $<\mathrm{t}$ tabel

Ha : diterima jika, $\mathrm{t}$ hitung $>\mathrm{t}$ tabel

Penelitian ini dilakukan di UPTD Sanggar Kegiatan Belajar (SKB) Kota

Binjai di Jl. Samanhudin No. 16 A, Kel. Satria, Kec. Binjai Kota.

Penelitian ini dilakukan selama 2 bulan mulai dari Mei - Juli 2019 


\section{HASIL PENELITAN DAN PEMBAHASAN}

Pembahasan yang dikemukakan dalam penelitian ini adalah hasil temuan dan hasil pengelolahan data yang berkaitan dengan jawaban atas pertanyaan penelitain yang telah dikemukakan pada rumusan masalah. Berdasarkan rumusan masalah yang dikemukakan pada BAB I, karena masalah merupakan sesuatu yang perlu dipahami dan dicarikan jawabannya, agar masalah dapat terjawab atau dipecahkan dengan baik maka masalah harus dirumuskan secara spesifik.

1. Seberapa baik iklim kerja organisasi di SKB Kota Binjai

Tagius (Muhammad 2007:82) mengemukakan bahwa "Iklim organisasi adalah kualitas yang relatif abadi dari lingkungan internal organisasi yang dialami oleh anggota-anggotanya, memhubungani tingkah laku mereka serta dapat diuraikan dalam istilah nilai-nilai suatu karakteristik tertentu dari lingkungan”. Artinya bahwa iklim kerja merupakan suatu keadaan yang menunjukkan suatu kehidupan yang saling berinteraksi, sehingga menimbulkan rasa senang atau tidak senang terhadap bidang pekerjaannya.

Berdasarkan hasil penelitian melalui uji kategori rata-rata nilai dengan menggunakan MS Excel, iklim kerja diperoleh dengan nilai rata-rata sebesar 3,18 lalu dikonsultasikan dengan skala likert, maka angka 3,18 berada dalam kategori baik, dengan demikian dapat diartikan bahwa iklim kerja pegawai di SKB Kota Binjai baik.Adapun tentang iklim kerja itu sendiri dapat dilihat dari tiap indikator yaitu:

a. Fisik

Fisik disini meliputi kebersihan dan keselamatan gedung, penggunaan sumber daya secara hemat dan efesien, kenyamanan serta keindahan ruang kerja pegawai. Berdasarkan perhitungan (dilampirkan) nilai skor rata-rata kondisi fisik adalah 3,05. Hal ini berarti iklim kerja telah memiliki fisik yang dikategorikan baik.

Kondisi fisik SKB Kota Binjai dikatakan baik karena dalam penataan meja diruang kerja pegawai sudah tertata baik, kondisi bangunan ruang kerja pegawai sangat kokoh dan juga ruang kerja pegawai memiliki pencahayaan dan ruang kerja yang jauh dari polusi udara. Ruangan kerja pegawai di SKB Kota Binjai memiliki penyimpanan barang yang baik. Sedangkan untuk warna dinding dari ruang kerja pegawai sudah baik karena tidak menimbulkan pantulan cahaya yang dapat mengganggu ketenangan pegawai SKB Kota Binjai dalam melakukan pekerajannya.

b. Aspek Sosial

hubungan dengan saling menghormati dan memiliki rasa bangga yang dapat dilihat ketika bercerita tentang keindahan dan kedamaian SKB Kota Binjai. Adanya keharmonisan tersebut 
mendukung iklim kerja yang menyenangkan. Pada indikator ini memiliki skor rata-rata sebesar 3,36. Hal ini berarti iklim kerja pegawai menunjukkan kondisi aspek sosial dikategorikan sangat baik. Kondisi aspek sosial di SKB Kota Binjai dikatakan sangat baik karena sudah terjalin dengan sangat baik sikap saling memaafkan sesama pegawai dan juga sikap saling menghormati antar pegawai.

c. Sistem Sosial

Sosial yang dimaksud dalam hal ini adalah adanya pembagian tugas yang jelas, adanya pembinaan terhadap bawahan, terlibatnya seluruh pegawai dalam pengambilan keputusan, berlangsngnya komunikasi dua arahn antara pegawai. Berdasarkan perhitungan rata-rata skor pada indikator ini diperoleh sebesar 3,26. Sehingga indikator sistem sosial pada variabel iklim kerja dikategorikan sangat baik. Sistem sosial di SKB Kota Binjai dikatakan sangat baik karena SKB Kota Binjai memiliki struktur organisasi dan kejelasan struktur tugas pegawai yang sangat baik. Dalam pemberian tugas dalam pekerjaan yang sesuai dengan latar belakang pegawai di SKB Kota Binjai masih dalam kategori baik. Terjalinnya komunikasi yang sangat baik antara sesama pegawai. Sistem demokrasi terjalin dengan baik pada saat pengambilan keputusan di SKB Kota Binjai.

d. Budaya

Budaya yang dimaksud dalam penelitian ini adalah adanya nilainilaimoral dan semangat untuk memberikan pelayanan bagi masyarakat. Artinya bahwa terciptanya nilai kesopanan, kesusilaan, dan moral serta agama antar pegawai untuk menciptakan pelayanan sesuai dengan nilai yang ada. Nilai skor rata-rata pada indikator ini yaitu 3,05 sehingga kondisi budaya pada indikator iklim kerja dikategorikan baik.Kondisi budaya di SKB Kota Binjai di kategorikan baik karena adanya keinginan pegawai untuk menambah wawasan dengan cara mencari dari media masa terkait tugas pegawai, dan pegawai mampu berfikir positif dalam penyelesaian tugasnya serta cepat dan tanggap dengan situasi dan kondisi saat bekerja dengan baik.

2. Seberapa baik motivasi kerja pegawai di SKB Kota Binjai

Menurut German (Kadarisman, 2013:274) motivasi adalah pendorong seseorang untuk berbuat, dan berperilaku. Dengan kata lain motivasi diartikan sebagai kekuatan, dorongan, kebutuhan, semangat tekanan atau mekanisme psikologi yang mendorong seseorang atau sekelompok orang demi keberhasilan organisasi maka tercapai pula tujuan pribadi para anggota/pegawai yang bersangkutan. 
Berdasarkan hasil perhitungan skor rata-rata nilai dengan menggunakan Ms Excel, motivasi kerja diperoleh skor rata-rata sebesar 3,14 lalu dikonsultasikan dengan skala likert, maka angka 3,14 berada dalam kategori tinggi. Dengan demikian dapat diartikan bahwa motivasi kerja pegawai di SKB Kota Binjai berada dalam kategori baik.

Adapun tentang motivasi kerja pegawai dapat dilihat dari indikator sebagai berikut :

\section{a. Prestasi Kerja}

Prestasi kerja adalah hasil kerja yang dicapai oleh seseorang tenaga kerja dalam melaksanakan tugas dan pekerjaan yang dibebankan kepadanya. Berdasarkan perhitungan nilai rata-rata prestasi kerja diperoleh sebesar 2,90 sehingga dikategorikan bahwa prestasi kerja pegawai di SKB Kota Binjai adalah baik. Prestasi kerja pegawai dikategorikan baik karena pegawai berusaha menyelesaikan pekerjaan dengan hasil dan berdaya guna, pemimpin memberikan kesempatan kepada pegawai untuk mengembangkan potensi yang ada pada dirinya, pegawai giat bekerja karena adanya kesempatan untuk menduduki posisi tertentu, dan pemimpin memberikan penghargaan untuk hasil kerja yang memuaskan.

b. Tanggung jawab

Tanggung jawab adalah kesanggupan pegawai dalam menyelesaikan tugas dan pekerjaan yang diserahkan kepadanya dengan sebaik-baiknya dengan tepat waktu serta berani memiliki resiko ataupun keputusan yang diambilnya atau tindakan yang dilakukannya. Berdasarkan hasil pengelolaan data diperoleh nilai rata-rata tanggungjawab pegawai sebesar 3,22. Dengan demikian maka indikator tanggungjawab kerja dikategorikan baik. Indikator tanggungjawab dikategorikan baik jika pemimpin tidak hadir pegawai tetap melaksankan tugasnya dengan baik, dalam menyelesaikan maslaah pemimpin bertindak bijaksana, pegawai diberikan peluang untuk meningkatkan kemampuan dan keterampilannya, serta para pegawai lebih mengutamakan pekerjaan dibandingkan kepentingan yang lainnya.

c. Kerjasama

Kerjasama adalah kemampuan pegawai untuk belajar bersamasama, bekerja dengan orang lain dalam menyelesaikan tugas dan pekerjaan. Nilai rata-rata kerjasama di SKB Kota Binjai adalah 3,28 dengan kategori sangat baik. Kerjasama dikategorikan snagat baik karena pegawai mau belajar bersama dengan rekan kerja lainnya, setiap pegawai mau menerima saran dan kritikan, serta 
berusaha membina kerjasama yang sehat dan hubungan yang baik dengan rekan kerja di kantor.

d. Disiplin

Disiplin adalah kesanggupan seorang pegawai untuk mentaati segala keadaan, peraturan perundang-undangan dan peraturan kedinasan yang berlaku. Mentaati peraturan kedinasan yang diberikan oleh atasan yang berwenang, serta sanggup untuk tidak melanggar aturan yang telah ada baik secara tertulis maupun tidak tertulis. Nilai rata-rata disiplin dalam motivasi kerja adalah 3,16 dengan kategori baik. Disiplin kategori di SKB Kota Binjai dikategorikan baik karena pegawai tiba dan pulang tepat waktu dan berusaha tidak meninggalkan kantor saat jam kerja dalam kategori baik. Pegawai tidak mengeluh dalam melakukan pekerjaan dikategorikan baik.

3. Hubungan iklim kerja organisasi dengan motivasi kerja pegawai di SKB Kota Binjai

Dalam program SKB masalah iklim kerja sangatlah berperan dan berhubungan terutama dalam hal motivasi kerja agar setiap pegawai dalam melaksanakan tugas dan tanggungjawab bisa sesuai dengan tujuan dan harapan semua unsur pegawai. Dalam hal ini tujuan SKB dapat tercapai dan dilihat apabila lingkungan kerja menyangkut seluruh aspek sosial baik formal maupun nonformal yang dirasakan oleh para pegawai dan lingkungan itu dapat memhubungani pekerjaannya.

Berdasarkan hasil perhitungan menggunakan korelasi diperoleh koefisien korelasi $r_{x y}=0,789$. Hal ini memiliki arti bahwa iklim kerja memiliki hubungan terhadap motivasi kerja. Sedangkan dari hasil determinasi dapat diketahui hubungan iklim kerja dengan motivasi kerja sebesar $62,2 \%$ dan sisanya 37,8\% merupakan variabel-variabel lain yang turut mendukung motivasi kerja pegawai di SKB Kota Binjai namun tidak diteliti oleh penulis.

Sedangkan dalam menguji keberartian koefisien korelasi diperoleh hasil. Hasil dari perhitungan diketahui taraf signifikansi 5\% dan $\mathrm{dk}=\mathrm{n}$ 2 yaitu $30-2=28$, maka diperoleh $t_{\text {hitung }}>t_{\text {tabel }}$ yaitu $11,056>1,701$. Maka Ho ditolak dan Ha diterima artinya ada hubungan antar iklim kerja pegawai dengan motivasi kerja di SKB Kota Binjai.

Berdasarkan hasil perhitungan tersebut, dapat dilihat bahwa hubungan iklim kerja dapat memberikan konstribusi yang positif dengan motivasi kerja di SKB Kota Binjai. Terbentuknya iklim kerja yang kondusif pada 
tempat kerja dapat menjadi faktor penunjang bagi peningkatan kinerja sebab kenyamanan dalam bekerja membuat pegawai berpikir dengan tenang dan terkonsentrasi hanya pada tugas yang sedang dilaksanakan. Maka dapat disimpulkan apabila iklim kerja baik maka akan berdampak baik pula dengan motivasi kerja pegawai di SKB Kota Binjai

\section{SIMPULAN}

\section{Kesimpulan}

1. Iklim kerja organisasi di SKB Kota Binjai tergolong baik. Dalam 4 aspek yaitu fisik, aspek sosial, sistem sosial dan budaya dengan nilai rata-rata 3,72 .

2. Motivasi kerja pegawai di SKB Kota Binjai tergolong tinggi, dengan hasil skor rata-rata keseluruhan sebesar 3,14. Indikator unggulan dalam variable ini adalah kerja sama dengan nilai skor rata-rata 3,28.

3. Terdapat hubungan iklim kerja dengan motivasi kerja di SKB Kota Binjai. Dengan koefisien korelasi 0,789 yang signifikan 95\%. Besar korelasi iklim kerja pegawai terhadap motivasi kerja di SKB Kota Binjai sebesar 62,2\%. Dan selebihnya untuk 37,8 disebabkan faktor lain yang tidak termasuk dalam penelitian ini.

\section{Saran}

Berdasarkan hasil penelitian, permasalahan serta penjelasan dalam bab ini sebelumnya maka ada beberapa hal yang perlu dilakukan adalah:

1. Bagi Pegawai di SKB Kota Binjai

Secara umum dan keseluruhan motivasi kerja sudah tergolong baik, namun masih ada sedikit kekurangan dan kelemahan yang harus ditingkatkan yaitu terdapat dalam indikator prestasi kerja. Dalam hal ini motivasi kerja harus lebih meningkatkan kinerja dalam pencapaian tujuan SKB Kota Binjai. Adapun hal yang perlu dilakukan adalah :

a. Memberikan kesempatan kepada pegawai untuk mengikutin pelatihan-pelatihan yang ada.

b. Memberikan kesempatan untuk memperoleh pendidikan yang lebih baik kepada pegawai

c. Memberikan kesepatan kepada pegawai untuk mengikuti pelatihan

d. Memberikan bonus kepada pegawai yang tepat menyelesaikan tugasnya.

2. Bagi peneliti selanjutnya

Bagi peneliti selanjutnya yang tertarik untuk meneliti hubungan iklim kerja pegawai dengan motivasi kerja hendaknya peneliti tidak hanya menggunakan instrument angket dalam mencari data, akan tetapi lebih baik menggunakan beberapa teknik penelitian seperti wawancara dengan responden yang lebih luas lagi. Sehingga hasilnya jauh lebih 
objektif dan mampu memberikan solusi yang tepat bagi pemasalahan yang ada

\section{DAFTAR PUSTAKA}

Danim, Sudarwan. 2004. Motivasi Kepemimpinan dan Efektifitas Kelompok. Jakarta : Rineka Cipta.

Depdiknas. 2003. Undang-Undang Republik Indonesia Nomor 20 Tahun 2003, tentang Sistem Pendidikan Nasional. Jakarta: Cipta jaya.

Hasibuan, Melayu. 2007. Organisasi dan Motivasi Dasar Peningkatan Produktifitas. Jakarta : Bumi Aksara.

Hoetono, MA. 2005. Kamus Lengkap Bahasa Indonesia. Surabaya: Mitra Pelajar.

Kadarisman, M. 2013. Manajemen Sumber Daya Manusia. Depok: Raja Grafindo Persada.

Machfoedz, Ircham. 2009. Metodologi Penelitian. Yogyakarta: Fitramaya.

Manulang, M. 2003. Manajemen Sumber Daya Manusia. Bandung: Ciptapustaka Media Perintis.

Muhammad, Arni. 2007. Komunikasi Organisasi. Jakarta: Bumi Aksara.

Purba, P. 2016. Diktat Statistik Sosial II. Medan: Unimed

Rumengan, Jemmy. 2010. Metodologi Penelitian Dengan SPSS. Batam:

Saondi, Ondi \& Suherman, Aris. 2010. Etika Profesi Keguruan. Bandung: Refika Aditma.

Sastrohadiwiryo, Siswanto. 2003. Manajemen Tenaga Kerja Indonesia. Jakarta: Bumi Aksara.

Sudjana, H.D. 2000. Pendidikan Luar Sekolah. Bandung: Falah Production.

Sugiyono. 2013. Metode Penelitian Pendidikan. Bandung: Alfabet.

Sudijono Anas. 2004. Pengantar Statistik Pendidikan. Jakarta: Raja GrafindoPerkasa.

Supardi. 2013. Kinerja Guru. Jakarta: Raja Grafindo Persada.

Terry, George R. 2009. Prinsip -Prinsip Manajemen, Cetakan Kesepuluh, Jakarta: PT. Bumi Aksara.

Universitas Negeri Medan. Pedoman Penulisan Skripsi Fakultas Ilmu Pendidikan. Medan: Unimed 
Usman, Husaidi \& Setiady Purnomo. 2006. Pengantar Statistik. Jakarta: Bumi Aksara.

Wahyudin, Imam. 2012. Mengejar Profesionalisme Guru Strategi Praktis Mewujudkan Citra Guru Profesional. Jakarta: Prestasi Pustakakarya.

Winardi, J. 2001. Motivasi dan Pemotivasi Dalam Manajemen. Jakarta: Raja Grafindo Persada. 